\title{
MULTICULTURAL EDUCATION: EFFORT IN OVERCOMING PROBLEMS OF CULTURAL CONFLICT IN INDONESIA
}

\author{
Muhammad Rasyid Ridho ${ }^{1}$, Tumin ${ }^{2}$ \\ ${ }^{1}$ Universitas Negeri Malang, Malang, Indonesia \\ ${ }^{2}$ Universitas Muhammadiyah Yogyakarta, Yogyakarta, Indonesia \\ *Corresponding Address: muhammad.rasyid.2101328@students.um.ac.id
}

Received: 15 October 2021 | Approved: 27 December 2021 | Published: 26 January 2022

\begin{abstract}
The purpose of the study was to determine the concept of multicultural education, multicultural education for conflict resolution, the implementation of multicultural education in educational units, and the decision of the curriculum of multicultural education. This study uses a qualitative description method with the nature of research literature research. As a result of this study, people respect each other more because the concept of multicultural education aims to provide solutions and minimize conflicts caused by multidimensional and heterogeneous social situations. Can understand that respect unity and justice diversity context. Multicultural education basically exists to deal with conflict phenomena in multicultural societies. Multicultural education should be applied as soon as possible and also focus on the values that exist in society, rather than focusing solely on the knowledge aspect. The multicultural education curriculum needs to actually present important content that explains the perspectives of many people, based on the assumption that there is no unified interpretation of historical truth, emphasizing different cultural perspectives. Advocates the principles of unity and unity and provides an understanding of cultural differences.
\end{abstract}

Keywords: Education Multicultural; Cultural Conflict; Society.

Abstrak: Tujuan dari penelitian ini adalah untuk menentukan konsep pendidikan multikultural, pendidikan multikultural untuk resolusi konflik, pelaksanaan pendidikan multikultural di satuan pendidikan, dan keputusan kurikulum pendidikan multikultural. Penelitian ini menggunakan metode deskriptif kualitatif dengan jenis penelitian studi kepustakaan. Hasil penelitian ini adalah konsep pendidikan multikultural diharapkan mampu menjadi solusi dan meminimalisir terjadinya konflik yang disebabkan oleh kondisi masyarakat yang majemuk dan heterogen, sehingga masyarakat mempunyai pemahaman untuk lebih menghargai dan menghormati agar terwujud persatuan dan keadilan yang dirajut dengan bingkai kebhinekaan. Pendidikan multikultural pada dasarnya hadir untuk mersepon fenomena konflik di tengah masyarakat yang berwajah multikultural. Dalam penerapannya, pendidikan multikultural harus diterapkan dan terfokus pada nilai-nilai yang ada dalam masyarakat. Kurikulum pendidikan multikultural sejatinya perlu merepresentasikan isi materi yang mengambarkan perspektif banyak orang, didasarkan pada asumsi bahwa tidak ada penafsiran kebenaran sejarah, dan menekankan budaya perspektif berbeda. Menganjurkan prinsip-prinsip persatuan dan kesatuan, serta memberikan pemahaman tentang budaya perbedaan.

Kata kunci: Pendidikan Multikultural; Konflik Budaya; Masyarakat. 


\section{INTRODUCTION}

Indonesia is an archipelagic country which consists of various cultures, ethnicities, religions, as well as skin color, this is what causes the formation of the forerunner of the slogan "Bhineka Tunggal Ika" which is different, but still one. Cultural diversity and national traditions require the government to pay more attention to the psychology of society in developing policies, including education policies. This is because policies that seem to conflict with local culture and traditions are one of the causes of social crimes and can even lead to conflicts in people's lives (Suryana \& Rusdiana, 2015). Indeed, multicultural education in Indonesia has been discussed by education experts since 2000 in various workshops, symposia and various writings in the mass media and books. Names such as Munir Mulkan, Azyumardi Azra and also Musa Asy'ari are among Indonesian education experts who talk about the importance of multicultural education in Indonesia (Aly, 2011).

In Indonesia, multicultural education has only been recognized as an approach that is considered good by the heterogeneous-plural Indonesian people, especially in 1999-currently, which is a period that is very thick with autonomy and decentralization. Multicultural education developed in Indonesia since the development of democracy has been implemented as a counter to the policies of decentralization and regional autonomy (autoda) (Suryana \& Rusdiana, 2015). Which if this is not carried out carefully, it will plunge us into national divisions (national disintegration and separatism) (Mahfud, 2016).

Nowadays, the current of globalization demands the recognition of differences in the body of the Indonesian nation which consists of many ethnicities and religions. So the search for alternative forms of education is absolutely necessary in anticipation of conflicts in society, in fact in this case we need a form of education that seeks to maintain the culture of a society and transfer it to the next generation, foster values, foster friendship between students of various ethnicities, races, and religion, develop an attitude of mutual understanding. In this case, multicultural education is an answer for the issue of pluralism (Suryana \& Rusdiana, 2015). The importance of multicultural education is caused by the large number of Indonesians, coupled with various cultures, languages, religions, ethnicities, making them vulnerable to conflict.

Data from the Ministry of Social Affairs noted that almost 3,150 villages or 3.75\% of the total 84,000 villages in Indonesia were prone to social conflicts and became the scene of mass fights. The integrated team for handling social conflicts at the national level noted that in 2018-2019 there had been 71 social conflict events in various provinces, the indications were that they were motivated by political, economic, social and cultural issues (Ministry of Social Affairs: 3,150 Villages in Indonesia Prone to Social Conflict, 2020). This is also reinforced by the 2020 Criminal Statistics Data published 
by the Indonesian Central Statistics Agency, showing that during 2011-2018 the number of villages that became the scene of mass conflict was increasing, from around 2,500 villages in 2011 to around 2,700 villages. in 2014, and again increased to around 3,100 villages in 2018. The types of mass fights include fights between groups, fights between residents of villages, fights between residents and security forces, fights between students and fights between tribes. To anticipate the conflict, in this case the government issued Law no. 7 of 2012 concerning the handling of social conflicts. So with the issuance of these regulations, it is hoped that they will be able to overcome these social conflicts (Badan Pusat Statistik, 2020).

Throughout In 2017-2020 there have been many multicultural cases in Indonesia, especially in the world of education. Referring to the child complaint case data released by KPAI, in 2017 there were 12 cases of children victims of religious and cultural conflicts, in 2018 there were 9 cases, in 2019 there were 10 cases, and in 2020 there were 4 cases. As for the case of education, in this case children are victims of violence in schools (bullying), it shows that in 2017 there were 129 cases, 2018 there were 107 cases, in 2019 there were 46 cases and 2020 there were 76 cases (Data Kasus Pengaduan Anak 2016 - 2020| Bank Data Perlindungan Anak, 2021).

One of the triggers of cultural conflict is caused by misunderstandings from different cultures, both due to religious differences, ethnic differences and social strata. On this basis, multiculturalminded education is very important. That is, multicultural education is intended to be an alternative education that provides space for existence, recognition, and respect for other cultures (Sulalah, 2011). Therefore, multicultural education really needs to be applied in formal education as an alternative to various cultural conflicts in Indonesia.

Seeing the problems that have been described, the goal is to find out how the concept of multicultural education, multicultural education in overcoming conflict, the execution of multicultural instruction in educational units, and to know the multicultural education curriculum.

\section{METHODS}

The research method used is descriptive qualitative with the type of library research, namely research that examines or examines critically and deeply ideas, or the findings contained in the body of literature that have been obtained and then formulates theoretically about the topic being discussed. The data obtained from this research is a literature study through reference books, journals, and previous research results that have a relationship or continuity with what the author does and the author takes references in the last 10 years. Then the data can be analyzed in order to get a discussion 
and research conclusions so that the information that has been acquired is then given an knowledge and clarification in order that it may be understood properly via way of means of the reader.

\section{RESULTS AND DISCUSSION}

\section{Multicultural Education}

Education is a conscious effort to develop and shape innate physical and spiritual potential in accordance with the values that exist in society and culture (Mahfud, 2016). Defines education as a process of changing human behavior towards the point of maturity. One of the indicators of a mature human being has a superior and strong sense of cultural understanding. The point is that in addition to having knowledge and skills, humans must also have superior values and norms in their life. It is hoped that through education, humans are able to sort and choose which ones are good and which ones should be avoided and recognize their culture (Suryana \& Rusdiana, 2015). Explained that education is a necessary process to get balance and perfection in the development of individuals and society (Nurkholis, 2013).

The term multicultural is often used to describe the solidarity of different ethnic networks. Etymologically, the term multiculturalism comes from the words: multi which means many or different and social which means culture, from the two words which mean social diversity (Masamah $\&$ Huda, 2016). Culture that should be perceived is not culture from a narrow point of view, but culture is seen as a whole rationalization of the existence of various human beings. This rationalization will give birth to great knowledge, such as history, thought, culture, language and discourse.

The definition of multicultural education has been found in various literatures regarding the purpose of multicultural education. James Bank defines changes in thinking in multicultural education as a means or renewal, and the structure of educational institutions such different as male and female students, students with special needs, and students of races and cultures. The educational process that aims at groups has the same opportunity to support achievement in school (Suryana \& Rusdiana, 2015). This statement was reinforced by Ainul Yaqin who was quoted by Kholik explaining that multicultural education is an educational strategy that applies to all types of subjects, by taking advantage of cultural differences that exist among students, such as ethnicity, religion, language, gender, social characteristics, race, ability, and age, it will be more effective and easier (Kholik, 2017).

Multicultural education is the process of developing all student potential through the application of educational concepts based on utilizing the diversity that exists in the community, especially those 
of students such as ethnic diversity, culture, language, religion, social status, gender, ability, age, ethnicity. and race (Rohman \& Ningsih, 2018). Multicultural education is education that leads to abilities without any barriers or distinctions, so that students are seen from their abilities not from class, religion, race, language and ethnicity. Kamanto Sunarto also explained that multicultural education can be interpreted as education for cultural diversity in society, but it can also be interpreted as education that offers cultural diversity in society (Rosyada, 2014). Meanwhile, defines multicultural education as a majority rule way to deal with education and learning aimed at promoting cultural pluralism in a world that is interdependent with culturally diverse societies (D'hondt et al., 2021).

As a multi-ethnic and plural country, multicultural education is actually presented as an answer to various cultural problems faced in Indonesia. With a population of abundant human resources, it is very vulnerable to conflict, whether religious conflict, cultural conflict, racial conflict, gender conflict, and ethnic conflict, with that it is hoped that multicultural education can be an answer to various problems that arise in the community so that a community that breathes is realized. Pancasila which emphasizes unity, togetherness, mutual openness, and being able to respect differences.

\section{Resolving Conflict Through Multicultural Education}

\section{Multicultural Education Concept}

According to Wilkerson the term "multicultural" refers to the relocation of "peripheral cultures" to "dominant cultures" and social diversity in terms of "gender," "social class," and others as well as differences religious. Troyna argues that one of the crucial problems in a multicultural society is how to ensure that everyone has relatively equal opportunities to thrive, even if he or she is a member of a minority (Nurwanto \& Cusack, 2017). The importance of multicultural education can be seen from the reality and condition of Indonesian society which consists of various ethnic, religious and linguistic and cultural differences. This situation is coupled with a population of almost 210 million people, in which there are various sects of belief, culture, and various languages (Mania, 2010). These conditions and phenomena are one of the factors that must be considered and taken into account together to be taken into consideration so that they are included in educational programs. This fact is motivated by a multicultural culture in this context as a basis and foothold in making a conceptual framework and developing the vision, mission and goals of the educational institution (Sangadji, 2016).

According explained that in building a multicultural Indonesia there are three things that can be realized if: 
a. The concept of multiculturalism is widespread and can be understood through its multicultural urgency and the desire of the Indonesian people at the national or local level to take over and direct their lives.

b. There are similarities in the views of experts regarding the importance of multicultural education in the life of the nation and state.

c. Other ways that are expected to be able to be done in order to realize these ideals (Mahfud, 2016).

Multicultural education is an educational strategy and concept based on leveraging the diversity that exists in society, especially ethnic diversity, culture, language, religion, social status, gender, abilities, age and race. Is a form of education that applies and most importantly, this strategy aims to increase students' awareness to always behave humanist, pluralist, and democratic (Mania, 2010).

ThereforeIt is hoped that the concept of multicultural education can be a solution and minimize conflicts caused by the conditions of a pluralistic and heterogeneous society, so that people have an understanding to be able to respect each other, respect each other and have an open mind to real differences. In line with Mahfud explained that multicultural education must be presented in the world of education, because education is the most powerful tool to raise awareness (consciously) to the community, to prevent ethnic, cultural, and religious conflicts. Multiculturalism is a basic principle for recognizing and appreciating diversity which will greatly assist changes in social behavior that are conducive and promising in the midst of diverse people's lives (Suryana \& Rusdiana, 2015).

\section{Multicultural Education in Overcoming Conflict}

The very diverse culture of Indonesian society is a challenge for educational institutions, these differences should be an advantage and not a source of division. At least two things are the big responsibility of multicultural education, namely: Indonesian people must be ready to face various cultural flows from outside in this era of globalization, and be able to unite their own nation which consists of various cultures (Mahfud, 2016). The development of increasingly massive technological flows requires that people must be able and quickly adapt to cultural developments that occur in Indonesia, without having to leave the old culture brought by their ancestors. This cultural development must of course be balanced with knowledge, especially multicultural knowledge, which means that people must be ready to accept all cultural differences so that they are vulnerable to conflict. Moreover, with a variety of cultures, it is hoped that they will be able to unite the nation itself, as hoped by the founders of this nation.

In terms of education, multicultural education is an implementation and education strategy based on the use of diversity for students, such as the diversity that exists in society, especially the 
diversity of ethnicity, culture, language, religion, social status, and gender. draft. And race. The main goal of multicultural education is to overcome all differences in society and increase students' awareness to act humanely, pluralistically and democratically. Basically, in this multicultural education, teachers must know science and not only teach subjects professionally, but also convey the core values of multicultural education such as democracy, humanity, and multiculturalism. So with this kind of education, students are expected to be able to maintain morality, discipline, caring, humanism, and honesty in their daily activities (Masamah \& Huda, 2016).

Operationally, the transformation of education with a multicultural perspective is basically to respond to the phenomenon of conflict in the midst of a multicultural-faced society. The face of multiculturalism in this country until now is like a fire in the husks which one day could arise due to the heated political, religious, socio-cultural temperature that allows the conflict to re-emerge (Unwanullah, 2012). Therefore, the role of education here is very much needed as a transformation of values as well as awareness and provide understanding for a society where conflict cannot be fostered properly.

\section{Implementation of Multicultural Education in Education Units}

Multicultural education was born to provide equal opportunities for all children. The same thing was conveyed by Banks (1993) who said that the purpose of multicultural education is to organize schools in such a way that students from diverse ethnic groups experience equal education (D'hondt et al., 2021). Therefore, the group must be peaceful and need to understand each other and end differences, because nothing should be sacrificed for unity, but still emphasizes the common goal of achieving unity (Permana \& Ahyani, 2020) so to make it happen the role of educational institutions or units is needed because it is a place for transformation and transfer of knowledge and noble values. These noble values can be built as early as possible through basic education units, so it is hoped that in the future the noble values that have been fostered can be applied in life and socially amidst the diversity of a multicultural society.

Lynch and Hanson argue that children generally develop at the age of five years, so as early as possible multicultural education should be started so that children have a good cultural understanding. Children at this age can recognize the differences and similarities of race, ethnicity, and other cultural groups, therefore, it is time to increase cultural awareness and apply it through multicultural education. Indeed, multicultural education is education for everyone, regardless of race, gender, class, socioeconomic status, or physical ability (Phoon et al., 2013).

Education Multiculturalism in its embodiment must prioritize values in living together, in society, and as a nation, not only focusing on aspects of knowledge and understanding of socio- 
cultural values (Azra, 2019). This value aspect will lead to an understanding of the formation of a multicultural society based on national insight. Therefore, a precise strategy is needed that can be implied in multicultural education in education units, this is as explained by Najmina (2018) that education experts describe strategies in the implications of multicultural education in schools, including: 1) building an inclusive diversity paradigm in the school environment, 2) respecting language diversity in schools, 3) building gender sensitive nature in schools, 4) building critical understanding and empathy for injustice and social differences, 5) develop anti-ethnic-discrimination attitudes, 6) respect differences in abilities, and 7) respect age differences.

In this context, teachers need to foster multicultural awareness by building a spirit of empathy, equality and tolerance for students. By emphasizing that everyone in all backgrounds has the same rights as citizens. A group must not control or infringe the rights of another group. The majority group should not dominate the minority group. The value of multicultural institutions is important in Indonesian education. Students must be instilled with a spirit of equal cooperation and must not be discriminated against based on race, ethnicity, religion or gender (Masamah \& Huda, 2016).

\section{Multicultural Education Curriculum}

The important purpose of the birth of a multicultural curriculum concept is to help students acquire knowledge as well as attitudes and skills that can carry out effective roles in the life line of a pluralistic-democratic society such as interacting, negotiating and communicating with the community and groups so as to create a social order that is moral (Suryana \& Rusdiana, 2015). To realize this, multicultural education should be included in the educational curriculum, so that in the end a multicultural society can be realized (Mahfud, 2016). This is in line with Banks' view (1992, 2001) multicultural education should be integrated into the entire curriculum plan and not instructed individually (Phoon et al., 2013).

In other words, speaking of the situation in Indonesia at that time, it is clear that multicultural education should be developed in Indonesia. In this way, "Bhinneka Tunggal Ika" can be interpreted appropriately, accurately, in a balanced and proportional manner. Through this policy, it is possible to realize "Indonesia's unity" by fostering the spirit of nationalism as expected (Adhani, 2014).

In implementing a multicultural curriculum in education, it is necessary to rely on these principles as described (Suryana \& Rusdiana, 2015), that is:

a. The multicultural curriculum must represent the content of the material that describes the views and perspectives of many people.

b. Based on the assumption that there is no single interpretation of historical truth. 
c. Emphasizes diverse cultural points of view.

d. Prioritizing the principles of togetherness and unity as well as eradicating negative views regarding race, religion, and culture.

e. Provide an understanding of diverse cultural differences so as to encourage the individual to broaden his knowledge of his culture.

The curriculum is an educational plan that provides guidance and guidance to educators regarding the type, scope, sequence of content, and the educational process. Therefore, the curriculum has a central position in the entire educational process, namely as a guide and guide for teachers in the process of implementing learning in schools (Suniti, 2014). As part of educational planning, the curriculum contains the objectives to be achieved, the material to be delivered, teaching equipment or tools, and the teaching time agenda. As a system, the curriculum must focus on a school organizational framework system or school system that involves setting policies regarding the curriculum, personnel atmosphere, procedures for developing, implementing, assessing, and also improving the curriculum.

In the process of developing a multicultural curriculum, there are four things that must be considered according to Hamid Hasan, namely: 1) students must be positioned as subjects in learning, 2) learning methods are determined by their cultural background, 3) the cultural environment in society and in students is a student's cultural habit, and 4) the cultural environment becomes a source of learning for students.

Learning about diversity needs to be done in a situation where teachers, students and community members mutually support and contribute to providing an understanding of diversity. Of course, the involvement of stakeholders will provide effort and can encourage and support teachers, parents and community members to cooperate with each other in supporting the learning needs of each child (Phoon et al., 2013). Seeing the very diverse Indonesian society, the multicultural curriculum should be applied in educational units as an entity for multi-cultural and multi-ethnic diversity. The multicultural curriculum actually encourages students to become democratic and humanistic individuals, in its implementation, an emphasis and appreciation is needed to become human beings with integrity and quality, not only smart but also moral so that in democracy one can respect and respect the rights of others to live peacefully side by side.

\section{CONCLUSION}

Multicultural education is a new discourse for the Indonesian educational community. In fact, multicultural education was born out of various cataclysms that occur in a society rich in diverse 
cultures. The existence of the concept of multicultural education is expected to help the unity of educational institutions as a remedy for the symptoms of conflicts that occur in the community. Known for its diverse cultural background, Indonesia must be a role model and model for other countries. This diversity allows social groups to unite, and the existence of multicultural education that teaches students from the beginning is the answer to this reality. The concept of multicultural education is the solution, minimizing conflicts caused by multiple and heterogeneous social situations and deepening the understanding that people can respect and respect each other open to each other. Educational transformation from a multicultural perspective should respond essentially to the conflict phenomenon in the midst of a multicultural society. So the role of education here is very much needed as a transformation of values as well as awareness and provide understanding for a society where conflict cannot be fostered properly. Seeing the very diverse Indonesian society, the multicultural curriculum should be applied in educational units as an entity for multicultural and multiethnic diversity. The multicultural curriculum actually encourages students to become democratic and humanistic individuals.

\section{REFERENCES}

Adhani, Y. (2014). Konsep Pendidikan Multikultural Sebagai Sarana Alternatif Pencegahan Konflik. SOSIO DIDAKTIKA: Social Science Education Journal, 1(1). https://doi.org/10.15408/sd.v1i1.1211

Aly, A. (2011). Pendidikan Islam Multikultural di Pesantren: Telaah terhadap Kurikulum Pondok Pesantren Modern Islam Assalam Surakarta. Pustaka Pelajar.

Azra, A. (2019). Revitalisasi Wawasan Kebangsaan Melalui Pendidikan Multikultural. Jurnal Ledalero, 18(2), 183-202. https://doi.org/10.31385/j1.v18i2.185.183-202

Badan Pusat Statistik. (2020). Statistik Kriminal 2020. BPS-Statistic Indonesia.

D’hondt, F., Maene, C., Vervaet, R., Van Houtte, M., \& Stevens, P. A. J. (2021). Ethnic discrimination in secondary education: Does the solution lie in multicultural education and the ethnic school composition? Social Psychology of Education, 24(5), 1231-1258. https://doi.org/10.1007/s11218-021-09651-w

Data Kasus Pengaduan Anak 2016 - 2020 | Bank Data Perlindungan Anak. (2021). KPAI R.N. https://bankdata.kpai.go.id/tabulasi-data/data-kasus-pengaduan-anak-2016-2020

Kemensos: 3.150 Desa di Indonesia Rawan Konflik Sosial. (2020). Media Indonesia. https://mediaindonesia.com/humaniora/365709/kemensos-3150-desa-di-indonesia-rawan- 
konflik-sosial

Kholik, N. (2017). Peranan Sekolah Sebagai Lembaga Pengembangan Pendidikan Multikultural. $1(2), 244-271$.

Mahfud, C. (2016). Pendidikan Multikultural. Pustaka Pelajar.

Mania, S. (2010). Implementasi Pendidikan Multikultural Dalam Pembelajaran. Lentera Pendidikan : Jurnal Ilmu Tarbiyah Dan Keguruan, 13(1), 78-91. https://doi.org/10.24252/1p.2010v13n1a6

Masamah, U., \& Huda, M. (2016). Multicultural Education and the Nationalistic Reality (Photograph the Role of Teachers in Building a Multicultural Awareness in Indonesia). QIJIS (Qudus International Journal of Islamic Studies), $4(1), \quad 68-81$. http://journal.stainkudus.ac.id/index.php/QIJIS/article/view/1578

Matsuroh. (2010). Kurikulum Pendidikan Berbasis Multikultural. Millah: Jurnal Studi Agama, 10, 71-83. https://doi.org/10.38153/alm.v3i1.28

Najmina, N. (2018). Pendidikan Multikultural Dalam Membentuk Karakter Bangsa Indonesia. Jupiis: Jurnal Pendidikan Ilmu-Ilmu Sosial, 10(1), 52-56. https://doi.org/10.24114/jupiis.v10i1.8389

Ningsih, Y. E., \& Rohman, A. (2018). Pendidikan Multikultural: Penguatan Identitas Nasional Di Era Revolusi Industri 4.0. UNWAHA Jombang, 1(September), 44-50. http://ejournal.unwaha.ac.id/index.php/snami/article/view/261

Nurkholis. (2013). Pendidikan Dalam Upaya Memajukan Teknologi. 1(1), 24-44.

Nurwanto, \& Cusack, C. M. (2017). Addressing Multicultural Societies: Lessons From Religious education curriculum Policy in Indonesia and England. Journal of Religious Education, 64(3), 157-178. https://doi.org/10.1007/s40839-017-0040-x

Permana, D., \& Ahyani, H. (2020). Implementasi Pendidikan Islam Dan Pendidikan Multikultural Pada Peserta Didik. Jurnal Tawadhu, 4(1).

Phoon, H. S., Abdullah, M. N. L. Y., \& Abdullah, A. C. (2013). Multicultural early childhood education: Practices and challenges in Malaysia. Australian Educational Researcher, 40(5), 615-632. https://doi.org/10.1007/s13384-013-0120-1

Rosyada, D. (2014). Pendidikan Multikultural Di Indonesia Sebuah Pandangan Konsepsional. Sosio Didaktika: Social Science Education Journal, 1(1). https://doi.org/10.15408/sd.v1i1.1200

Sangadji, K. (2016). Pendidikan Multikultural Dalam Pengembangan Kurikulum Perguruan Tinggi (Sebuah Kajian Kurikulum). Biosel: Biology Science and Education, 5(1), 38. 
MULTICULTURAL EDUCATION: EFFORT IN OVERCOMING PROBLEMS OF CULTURAL CONFLICT ...

Muhammad Rasyid Ridho, Tumin

https://doi.org/10.33477/bs.v5i1.483

Sulalah. (2011). Pendidikan Multikultural (Didaktika Nilai-nilai Universalitas Kebangsaan). UINMaliki Press.

Suniti. (2014). Kurikulum Pendidikan Berbasis Multikultural. Jurnal Edueksos, 3(2).

Suryana, Y., \& Rusdiana, A. (2015). Pendidikan Multikultural: Suatu Upaya Penguatan Jati Diri Bangsa Konsep, Prinsip, dan Implementasi. CV Pustaka Setia.

Unwanullah, A. (2012). Transformasi Pendidikan Untuk Mengatasi Konflik Masyarakat Dalam Perspektif Multikultural. Jurnal Pembangunan Pendidikan: Fondasi Dan Aplikasi, 1(1). 